\title{
The Recommend Strategy for Slow Learners Difficulties in Learning Speaking at Homeschooling
}

\author{
Devi Lusiana ${ }^{1, *}$ Anni Holila Pulungan ${ }^{2}$ Rahmad Husein ${ }^{3}$
}

\author{
${ }^{1}$ Universitas Negeri Medan \\ ${ }^{2}$ Universitas Negeri Medan \\ ${ }^{3}$ Universitas Negeri Medan \\ ${ }^{*}$ Corresponding author. Email: elfadevilusiana@gmail.com
}

\begin{abstract}
This research deals with recommending strategy use for slow learners' difficulties in learning speaking at Homeschooling Global Lentera Kasih Batam. This research was conducted by using qualitative research. The objective of this study was to recommend strategies in learning to speak English. The data of this study was obtained from documentation and interview. The techniques of collecting data that were applied in this research- are observation, interview and documentation. The data of this study obtained from the result of interview from teacher and parents of slow learners. The source of data in this study was slow secondary learners grade $\mathrm{X}$ and the English teacher. There were 2 English teachers, and 2 classes of secondary level learners in Homeschooling Global Lentera Kasih and both slow learners classes contains 4 students, in class X-1 they are FL, NM, RRH and PLG, while in class $\mathrm{X}-2$, they are DA, KT, SRN and FDF. The results were showed that Picture describing, role play and brainstorming were appropriate recommend strategies for teaching slow learners' in learning speaking.
\end{abstract}

Keywords: recommend, strategy, slow learners, learning, speaking.

\section{INTRODUCTION}

Speaking is the ability to convey information or expressing one's thoughts feelings in spoken language. Speaking ability should be mastered by students to facing global era. Moreover, by mastered speaking English students can communicate with other people in oral communication. The aims of teaching speaking are to improve the oral production of the students. As Richards and Renandya (2005) state that since the purpose of language teaching is to provide learners with communicative competence, classroom activities seem to be an important component of a language course.

Secondary learners describe as an institution that provides secondary education or called middle education. Some secondary schools provide both lower secondary education (12 to 15 years of age) and upper secondary education (15 to 18 years of age) but these can also be provided in separate schools. In Indonesia, schools typically admit pupils between 11 and 16 years of age.

Homeschooling refers to home education. The common understanding is homeschooling education model where a family chooses to be solely responsible for their children's education by using home as a base education.

At the beginning of 2020 due to the COVID-19 pandemic, all schools include homeschooling get the impact. UNESCO (2020) declares to support countries in their efforts to assuage the immediate impact of school closures, especially for the underprivileged, as well as facilitating the continuity of education for all through distance learning.

So based on the above explanation, learning Speaking English for slow secondary learners is not easy. Some problems can arise in slow secondary learners. Teachers must have strategy to overcome their difficulties in speaking as we know that, they have low learning achievement or below average than children in general. The special condition must be a challenge for the school especially for the English teacher so that the slow learner can speak in the classroom. 


\section{THEORETICAL FRAMEWORK}

Murcia (2000) states Speaking is an activity requiring the integration of many subsystems, all these factor combine to make speaking a second or foreign language a formidable task for language learners, yet for many people, speaking is seen as the central skill. In addition Brown (2001) divides speaking into two parts; monologue and dialogue. Monolog is the ability to give an uninterrupted oral presentation. It means that one speaker uses spoken language for any length of time, as in speeches, readings, news broadcasts, and like, the hearer must process long stretches of speech without interruption. And dialog is the ability to interact with one or more other speakers for transactional and interactional purposes. Dialogues involve two or more speakers and can be subdivided into those exchanges that promote social relationships (interpersonal) and those for which the purpose is to convey propositional or factual information (transactional).

Slow learners are regarded as learners who are unable to cope with the school task as normal learners to the same age. Triani and Amir (2013) point out slow learner as a child who has low learning achievement or below average than children in general.

Teaching strategy can be defined as ways that are implemented by teachers in teaching-learning process. Strategies in teaching is very crucial because it determine teachers' success in convey the material. William and Burden (2003) states that strategies used by teachers are the factor of success or failure in language learning for it is ultimately the strategies that determine what language instructions are and how they are conducted. In addition, Reiser and Dick (1996) also stated that teachers can use different strategies of teaching to achieve teaching-learning goals and objectives. These imply that it is teachers' responsibility to make students speak English by determine the suitable teaching strategies. Kayi (2006) states that there are some activities to promote speaking strategies those are: Discussion, Role Play, Simulations, Information Gap, Brainstorming, Storytelling, Interviews, Story Completion, Reporting, Playing Cards, Picture Narrating, Picture Describing and Find the difference.

This research was conducted by applying a descriptive research design. Bogdan \& Biklen (1992) proposed the descriptive qualitative design as the researcher's plan of how to proceed, while Potter (1996) states that Naturalistic design is when the research main focus is to observe person or persons in their natural state as undisturbed as possible.

The data of this study obtained from documentation and interview. The techniques of collecting data that was applied in this research- they are observation, interview and documentation. The data of this study obtained from the result of interview from teacher and parents of slow learners. The source of data in this study was slow secondary learners grade $\mathrm{X}$ and the English teacher. There were 2 English teachers, and 2 classes of secondary level learners in Homeschooling Global Lentera Kasih and both slow learners classes contains 4 students, in class X-1 they are FL, NM, RRH and PLG, while in class X-2, they are DA, KT, SRN and FDF.

\section{RESULT AND DISCUSSION}

Speaking strategy theory is obtained from Kayi (2006) that the proposed some activities to promote speaking strategies those are: Discussion, Role Play, Simulations, Information Gap, Brainstorming, Storytelling, Interviews, Story Completion, Reporting, Playing Cards, Picture Narrating, Picture Describing and Find the difference.

Slow learners personal data have been described such as: have limited cognitive capacity, low memory, impaired and lack of concentration and the inability to express ideas. This affects the attention of the slow learners who are relatively short, Finding and combining words, emotional immaturity, and shame makes other students unable to express ideas like common students. The table also shows that most of them 7 of 8 students were visual learners, and only one student was kinesthetic. From the slow learner's personal data, it was found that slow learner easier to understand learning visually, this was in line with the results of the interview between researcher and teachers. The data can be seen in the table below:

Table 1. Slow learner's basic personal data

\begin{tabular}{|l|l|l|l|}
\hline No & $\begin{array}{l}\text { Slow } \\
\text { Learners }\end{array}$ & $\begin{array}{l}\text { Learning } \\
\text { Style }\end{array}$ & $\begin{array}{l}\text { Description of } \\
\text { personal data }\end{array}$ \\
\hline $\mathbf{1 .}$ & FL & $\begin{array}{l}\text { Visual } \\
\text { learner }\end{array}$ & $\begin{array}{l}\text { Emotional immaturity } \\
\text { and short term } \\
\text { memory. }\end{array}$ \\
\hline $\mathbf{2 .}$ & NM & $\begin{array}{l}\text { Visual } \\
\text { learner }\end{array}$ & $\begin{array}{l}\text { Lack of attention to } \\
\text { the information } \\
\text { conveyed, difficult in } \\
\text { listening and short } \\
\text { term memory. }\end{array}$ \\
\hline 3. & RRH & $\begin{array}{l}\text { Visual } \\
\text { learner }\end{array}$ & $\begin{array}{l}\text { Difficulty finding and } \\
\text { combining words, } \\
\text { emotional immaturity, } \\
\text { low in listening and }\end{array}$ \\
\hline
\end{tabular}




\begin{tabular}{|l|l|l|l|}
\hline & & & short term memory. \\
\hline 4. & PLG & $\begin{array}{l}\text { Visual } \\
\text { learner }\end{array}$ & $\begin{array}{l}\text { Lack of attention to } \\
\text { the information } \\
\text { conveyed, short term } \\
\text { memory, cannot } \\
\text { concentrate on a } \\
\text { verbal lesson for more } \\
\text { than thirty minutes and } \\
\text { often absence }\end{array}$ \\
\hline $\mathbf{5 .}$ & DA & $\begin{array}{l}\text { Visual } \\
\text { learner }\end{array}$ & $\begin{array}{l}\text { shyness and unable to } \\
\text { express ideas, short } \\
\text { term memory }\end{array}$ \\
\hline $\mathbf{6 .}$ & KT & $\begin{array}{l}\text { Visual } \\
\text { learner }\end{array}$ & $\begin{array}{l}\text { Lack of confident, } \\
\text { lack of attention to the } \\
\text { information conveyed, } \\
\text { difficult in listening } \\
\text { and short term } \\
\text { memory. }\end{array}$ \\
\hline $\mathbf{7 .}$ & SRN & $\begin{array}{l}\text { Kinesthetic } \\
\text { learner }\end{array}$ & $\begin{array}{l}\text { Lack of attention to } \\
\text { the information } \\
\text { conveyed, difficulty } \\
\text { finding and combining } \\
\text { words and short term } \\
\text { memory. }\end{array}$ \\
\hline FDF & $\begin{array}{l}\text { Visual } \\
\text { learner }\end{array}$ & $\begin{array}{l}\text { Unable to express or } \\
\text { express ideas, verbal } \\
\text { disorder, short term } \\
\text { memory, difficulty } \\
\text { finding and combining } \\
\text { words, emotional } \\
\text { immaturity, and } \\
\text { shyness. }\end{array}$ \\
\hline
\end{tabular}

Two teachers agreed that the picture describing strategy was suitable strategy for slow learners, while the other teachers stated role plays and brainstorming were also the recommended strategies for slow learners. The recommend strategies for slow learners from the results of the interview can be seen in the following table.

Table 2. The Recommend Strategy

\begin{tabular}{|l|l|}
\hline \multicolumn{1}{|c|}{ YA } & \multicolumn{1}{|c|}{ F } \\
\hline Role Play & \\
\hline Brainstorming & \\
\hline Picture Describing & \\
\hline
\end{tabular}

From the table data analysis recommendation strategies used for slow learner it was found that $\mathrm{F}$ recommend picture describing as appropriate strategy for slow learners, while the results of the interview with YA, it found that there were 3 recommended strategies, namely brainstorming, role play and picture describing, but YA also emphasizing the picture describing as the appropriate strategy in learning speaking for slow learner. The explanation of the recommended strategy for slow learners can be seen from the following explanation.

\section{Data 1/I-24/R/ETF}

Bagaimana strategi pembelajaran yang efektif $\mathrm{R}:$ diterapkan untuk anak lamban belajar dalam belajar speaking? "what is the effective learning strategies be applied to the slow learners in learning to speak?"

Kalau strategi lebih masing-masing guru punya

T: strategi yah. Tapi kalau saya sendiri adalah saya lebih mendekatkan ee topic speaking itu pada kehidupan mereka. Itu strategi saya. Jadi ketika mereka sudah ditetapkan dengan topic dikehidupan mereka maka vocab-vocab itu akan muncul. Lalu setelah muncul maka mereka bisa merangkai untuk kalimat. Jadi saya lebih kepada adabtable dan mensosialisasikan kepada kehidupan mereka sehari-hari..All they activity something like that. Untuk strateginya berdasarkan pengalaman saya sih lebih kepada picture describing yah. Jadi ketika mereka ditawarkan visual ketika mereka lihat maka merekea mendiscribe lalu muncullah beberapa kosakata yang berkaikan dengan picture tersebut, lalu mereka merangkainya dalam bentuk kata-kata dijadikan dialog seperti itu. "Each teacher has a strategy, right? But for me, I am bringing the ee topic speaking closer to their lives. That's my strategy. So when they are fixed on the topic of their life then the vocabs will appear. Then after appearing they can string together for sentences. So, I prefer to socialize in their daily lives All they activity something like that. The strategy, based on my experience, is picture describing. So when they are offered a visual, when they see it, they describe it, then some vocabulary appears that relates to the picture, then they arrange it in the form of words to become a dialogue like that."

The data above shows that every teacher has a strategy in teaching students who are slow in learning to speak. as F said that Kalau strategi lebih masingmasing guru punya strategi yah. Tapi kalau saya sendiri adalah saya lebih mendekatkan ee topic 
speaking itu pada kehidupan mereka.However, the most suitable strategy for slow learners is picture describing as F stated that Untuk strateginya berdasarkan pengalaman saya sih lebih kepada picture describing yah. Jadi ketika mereka ditawarkan visual ketika mereka lihat maka merekea mendiscribe lalu muncullah beberapa kosakata yang berkaikan dengan picture tersebut, lalu mereka merangkainya dalam bentuk kata-kata dijadikan dialog seperti itu. In this case the teacher stated that the slow learner cannot respond quickly to the material they are learning, they need a stimulus and one of the appropriate stimuli is to apply the right strategy, and that strategy is picture describing because it stimulates them to express their opinions so that they are able to vocabulary related to the picture.

\section{Data 2/I-24/R/ETYA:}

R: Bagaimana strategi pembelajaran yang efektif diterapkan untuk anak lamban belajar dalam belajar speaking? "what is the effective learning strategies be applied to the slow learners in learning to speak?"

T: Strategi pembelajaran yang aktif yah itu bisa ee. Bisa kita gunakan sih. Strateginya ee seperti role play itu bisa kepada anak kita kasih, kemudian ada brainstorming misalnya ee kita kasih dulu ee misalnya tentang sekolah apa-apa aja sih aaa sekolah itu adanya gitu...Apa aja gitukan disekolah. Kemudian picture discribing itu selalu saya bilang Ee menjelaskan. Saya kasih dulu picturenya. Kemudian anak-anak itu menjelaskan tentang apa yang diamatinya...Begitu miss. Jadi strategi itu bisa kita gunakan Bisa efektif untuk anak lamban. Especially untuk anak speakingnya yah miss. "active learning strategy, We can use it anyway the strategy is like role playing, we can give our children, then there is a brainstorming, for example, we give it first, for example, about any school, the school is there ... Then picture describing I explained ...I gave the picture first. Then the children explained what they had observed... I see, miss. So that strategy we can use can be effective for the slow learners. Especially for the speaking, miss."

Further, data were obtained through interviews with the second teacher. In this data, the teacher suggests role play, brainstorming and strategies that can be applied to the slow learners in learning speaking, as YA said that Bisa kita gunakan sih. Strateginya ee seperti role play itu bisa kepada anak kita kasih, kemudian ada brainstorming however, pictures desribing is the main recommendation in teaching speaking to the slow learners. as YA said that Kemudian picture discribing itu selalu saya bilang Ee menjelaskan. Saya kasih dulu picturenya. Kemudian anak-anak itu menjelaskan tentang apa yang diamatinya. So from the analysis above it can be concluded that it cannot be denied that the slow learners will be easier to express their opinions by stimuli shown through pictures. Slow learners are easier to express their opinions in learning speaking from what they see. It means that visuals really help them express what is on their minds, so the recommended strategies in learning speaking for slow learners is picture describing, role play and brainstorming.

\section{CONCLUSION}

In the result of analysis data it was found that 7 of 8 students were visual learners, and only one student was kinesthetic. From slow learners personal data it can be concluded that slow learner students easier to understand learning visually, however the data analysis from interview between researchers and teachers proves that the recommended strategies for the slow learners were picture describing, role play and brainstorming as appropriate strategies for teaching slow leaner in learning speaking.

\section{ACKNOWLEDGMENTS}

The writer would like to express their highest gratitude and appreciation to family, friends, and lecturer, who have been very helpful, kind and patient in giving advice, ideas, guidance, assistance, and their valuable time during the process of writing this article. The writer also wish to express the sincere thanks to Dr. Anni Holila Pulungan and Dr. Rahmad Husein, M.Ed., for their support and advice.

\section{REFERENCES}

[1] Bogdan, C. Robert and Biklen. 1992. Qualitative Research for Education: An introductionto theory and Method. Boston: Allyin and Bacon.

[2] Bogdan, R. C. 1992. Qualitative Research for Education. California: Pearson A\&B.

[3] Brown, G and Yule, Y. 2001. Teaching the Spoken Language. Cambridge: Cambridge University Press, P13.

[4] Gann and Carpenter. 2017. STEM Teaching and Learning Strategies of High School Parents With Homeschool Students. Education and Urban Society Journa, P. 1-22. 
[5] Harmer, J. 2001. How to Teach English. London: Longman.

[6] Kayi, Hayriye. 2006. Teaching speaking: Activities to Promote Speaking in a Second Language. USA. The Internet TESL Journal, Vol. XII, No.11.

[7] Mercer, C. 1996. Learning Disabilities Definitions and criteria used by state education departments. Learning Disabilities Quarterly, 19: 217-232bro

[8] Miles, B., Huberman, Michael A. \& Saldana. 2014. Oualitative Data Analysis: a Methods Sorcebook. Edition 3. USA: SAGE.
[9] Mulyadi, Seto. 2007. Homeschooling Keluarga Kak Seto: Mudah, Murah, eriah, dan Direstui Pemerintah. Bandung: Kaifa PT Mizan Pustaka.

[10] Murcia, M. and Olshtain, E. 2000. Discourse \& Context in Language Teaching: a Guide for Language Teachers. Cambridge: Cambridge University Press

[11] Nani Triani dan Amir. 2013. Pendidikan Anak Berkebutuhan Khusus Lamban Belajar (Slow Learner). Jakarta: Luxima.

[12] William, M., and Burden, R. L. 2003. Psychology for Language Teachers: A Social Constructivist Approach. Cambridge: Cambridge University Press. 